\title{
Interactive comment on "Low-level mixed-phase clouds in a complex Arctic environment" by Rosa Gierens et al.
}

\section{Anonymous Referee \#1}

Received and published: 6 August 2019

Please ïňĄnd an attached PDF file, which is a review of "Low-level mixed-phase clouds in a complex Arctic environment" by Gierens et al.

Please also note the supplement to this comment: https://www.atmos-chem-phys-discuss.net/acp-2019-610/acp-2019-610-RC1supplement.pdf 2019. 